\title{
Short-term depression of inhibitory Purkinje cell synapses enhances gain modulation in the cerebellar nuclei
}

Dimitris Bampasakis ${ }^{1 *}$, Reinoud Maex², Neil Davey ${ }^{1}$, Volker Steuber ${ }^{1}$

From Twenty Second Annual Computational Neuroscience Meeting: CNS*2013

Paris, France. 13-18 July 2013

Information in neurons can be encoded by their action potential rate, thus making the transformation of input to output rate, the input-output (I-O) relationship, a core computational function. Introduction of a second input, often called modulatory input, can modify this I-O relationship in ways that correspond to different arithmetic operations [1]. Here, we examine the modulation of the slope of the I-O relationship, also referred to as gain modulation.

Gain modulation can be based on a wide variety of biophysical mechanisms, with short-term depression (STD) of excitatory synapses being one of them [2].
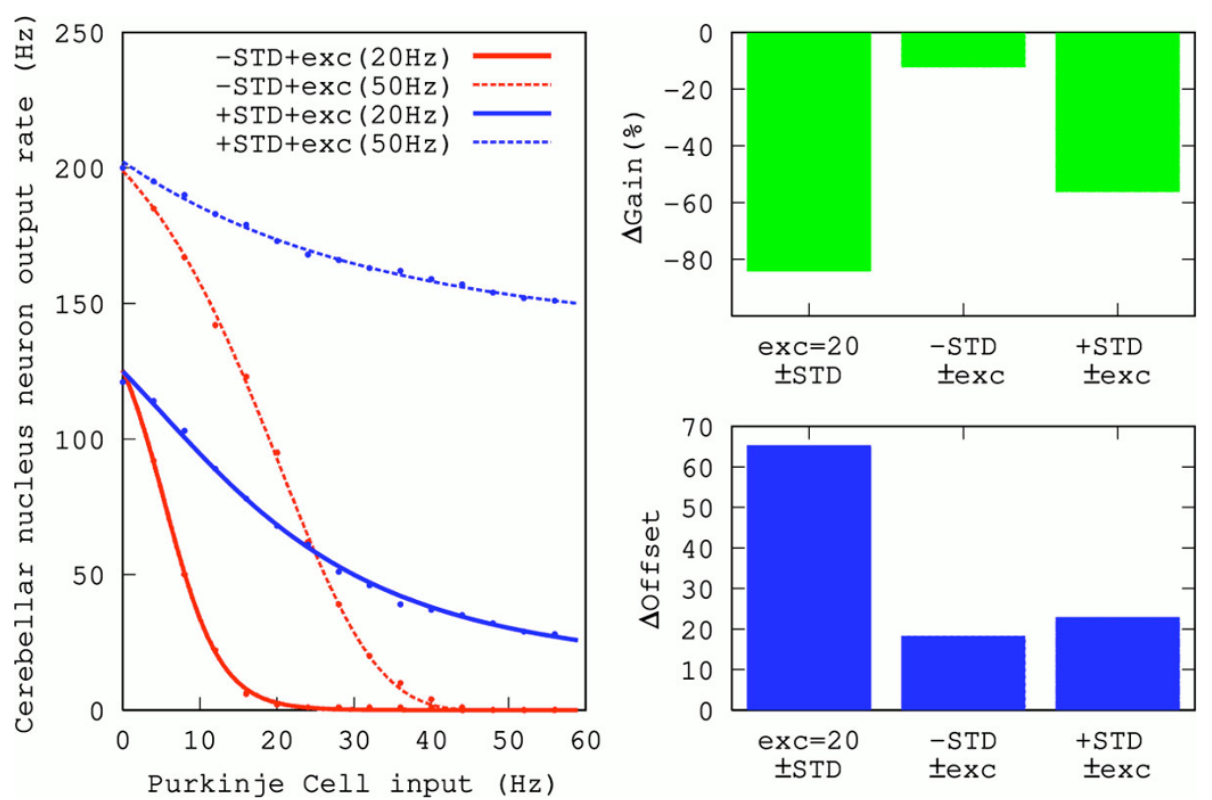

Figure 1 Gain change due to excitatory modulatory input. Left: Average output rate of the CN neuron as a function of PC inhibitory input, for $20 \mathrm{~Hz}$ and $50 \mathrm{~Hz}$ excitatory mossy fibre input. Dots and lines correspond to simulation data and fits of a Hill function, respectively. Right: Change in gain and offset (calculated as in [2]) in the presence and absence of STD for $20 \mathrm{~Hz}$ of excitatory rate (left bars), and for a change of the excitation from $20 \mathrm{~Hz}$ to $50 \mathrm{~Hz}$ in the absence (middle bars) and presence (right bars) of STD.

* Correspondence: d.bampasakis@herts.ac.uk

${ }^{1}$ Science and Technology Research Institute, University of Hertfordshire, Hatfield AL10 9AB, UK 
Commonly, gain modulation is studied by examining the effect of tonic or synaptic inhibition on the excitatory I-O relationship. However, some projection neurons, like cerebellar Purkinje cells (PCs), are inhibitory. Therefore, the opposite scenario, in which the effect of inhibition on output rate is being modulated by an excitatory input, may occur as well. As a previous study found that inhibitory synaptic input variability can change the output rate of neurons in the cerebellar nuclei $(\mathrm{CN})$ [3], the question arises how excitatory input can modulate this relationship.

Considering the excitatory input from mossy fibres (MF) onto $\mathrm{CN}$ neurons as modulatory, we investigated the effects on gain control exerted by STD of the inhibitory synapses that PCs make on a model $\mathrm{CN}$ neuron [3]. We found that STD at the inhibitory PC-CN synapse enhanced gain modulation (Figure 1). Thus, like STD at excitatory synapses, STD at inhibitory synapses can enable neurons to perform multiplicative operations on their inputs.

\section{Author details}

${ }^{1}$ Science and Technology Research Institute, University of Hertfordshire, Hatfield AL10 9AB, UK. ${ }^{2}$ Department of Cognitive Sciences, École Normale Supérieure, Paris 75005 , France.

Published: 8 July 2013

\section{References}

1. Silver RA: Neuronal arithmetic. Nature Reviews Neuroscience 2010, 11:474-489.

2. Rothman JS, Cathala L, Steuber V, Silver RA: Synaptic depression enables neuronal gain control. Nature 2009, 457:1015-1018.

3. Luthman J, Hoebeek FE, Maex R, Davey N, Adams R, De Zeeuw Cl, Steuber V: STD-dependent and independent encoding of input irregularity as spike rate in a computational model of a cerebellar nucleus neuron. Cerebellum 2011, 10:667-682.

doi:10.1186/1471-2202-14-S1-P374

Cite this article as: Bampasakis et al: Short-term depression of inhibitory Purkinje cell synapses enhances gain modulation in the cerebellar nuclei. BMC Neuroscience 2013 14(Suppl 1):P374.

\section{Submit your next manuscript to BioMed Central} and take full advantage of:

- Convenient online submission

- Thorough peer review

- No space constraints or color figure charges

- Immediate publication on acceptance

- Inclusion in PubMed, CAS, Scopus and Google Scholar

- Research which is freely available for redistribution

Submit your manuscript at www.biomedcentral.com/submit
C Biomed Central 